\title{
Is There an Impact of Family Support on Treatment in Young Hodgkin's lymphoma Patients?
}

\author{
Itır ŞİRINOĞLU DEMIRİZ*, Ceren GÜMÜŞEL ${ }^{2}$
}

\begin{abstract}
Objective: Hodgkin lymphoma (HL) is a B-cell derived cancer with a bimodal incidence pattern. First peak is in early adulthood; therefore, it is one of the most common cancers in young adult group. This age group represents $30-35 \%$ of all new HL cases. The impact of physical, psychological, and social status during treatment on patient and family members are the new interests of the literature. Due to crowded family life and multiple siblings in the Turkish society, patients can receive more family support than other countries nearby. We aimed to analyze the effects of experiences of these relatives during the patient's treatment period.
\end{abstract}

Methods: For the present study twenty young adults diagnosed with HL were invited. All the patients received chemotherapy in the outpatient unit. The relatives of these patients were included as family support analysis. SF-36 test was applied to the entire study population.

Results: Twenty patients were invited for the study, 11 of them were female $(55 \%)$ and 9 of them were male $(45 \%)$. The median age of twenty HL patients was 31.15 (22-40). Participants defined physical alterations, exhilaration loss or gain, pain relief, sociality, and mental healing changes according to the supportive care from their family members.

Conclusion: Cancer is a completely different experience for each patient and their family. Understanding the importance of family support and the need of the patient leads us to the optimal patient-based care and harmony for treatment.

Keywords: Hodgkin lymphoma, SF-36, family support

\author{
${ }^{I}$ Istanbul Aydin University, Faculty of Medicine, Department of Internal Medicine, Hematology \\ Unit, Istanbul, Turkey \\ ${ }^{2}$ Bakirkoy Dr. Sadi Konuk Training \& Research Hospital, Department of Internal Medicine, \\ Istanbul, Turkey \\ * Corresponding author \\ E-mail:dritir@hotmail.com; ORCID:0000-0001-7931-7104
}

Ceren Gümüşel: cerengumusel@hotmail.com; ORCID: 0000-0002-0108-1952

Received: 19 June 2021 Revised: 27 September 2021 Accepted: 10 October 2021

DOI: 10.17932/EJOH.2020.022/ejoh_v02i2002 
Is There an Impact of Family Support on Treatment in Young Hodgkin's lymphoma Patients?

\section{Introduction}

Hodgkin lymphoma (HL) is a B-cell derived cancer which is highly curable with a bimodal incidence pattern. First peak is in early adulthood; therefore, it is one of the most common cancers in young adult group. This age group represents 30-35 $\%$ of all new HL cases (1-4).

The impact of physical, psychological, and social status during treatment on patient and family members are the new interests of the literature. For example, the lower socioeconomic status has been linked to higher risk of late complications. Ruined harmony for treatment due to unsatisfactory family support may end with increased mortality after complications. Cancer experience is personally and profoundly stressful. The main reason for this is the uncertainty of treatment related decisions, relapse possibility, as well as fear of death (5-7).

The diagnosis of lymphoma affects the patient's life in many aspects. Social relations, spiritual and religious beliefs are a wide spectrum in the context for supportive care (8). Due to crowded family life and multiple siblings in the Turkish society, patients can receive more family support than other countries nearby. We aimed to analyze the effects of experiences of these patients and their relatives during the treatment period.

\section{Methods}

Twenty young adults diagnosed with HL were invited. All the patients received the same chemotherapy protocol in the outpatient unit. The family members, siblings or wife/husband or mother/father of the patients were included as family support analysis. SF-36 test was applied to the entire study population.

\section{Results}

Five percent of the patients were living alone, 19 patients were living with their family. Fifteen percent of the patients had to quit working after they were diagnosed with lymphoma. None of the participants had co-morbidities. All the patients were aware of their diagnosis and $95 \%$ of them had researched the disease via internet network. Participant demographic variables are summarized in Table 1. 
Table 1. Demographic variables of the patients

\begin{tabular}{|c|c|c|}
\hline \multicolumn{3}{|l|}{ Variable } \\
\hline Age & \multicolumn{2}{|c|}{$31.15(22-40)$} \\
\hline \multicolumn{3}{|l|}{ Mean (Range) } \\
\hline & $\mathrm{n}$ & $\%$ \\
\hline \multicolumn{3}{|l|}{ Gender } \\
\hline Male & 9 & 45 \\
\hline Female & 11 & 55 \\
\hline \multicolumn{3}{|l|}{ Education } \\
\hline None & 1 & 5 \\
\hline First grade & 5 & 25 \\
\hline Middle grade & 2 & 10 \\
\hline College & 6 & 30 \\
\hline Postgraduate & 6 & 30 \\
\hline \multicolumn{3}{|l|}{ Marital Status } \\
\hline Married & 12 & 60 \\
\hline Single & 8 & 40 \\
\hline \multicolumn{3}{|l|}{ Job } \\
\hline Yes & 5 & 25 \\
\hline No & 12 & 60 \\
\hline \multicolumn{3}{|l|}{ Social insurance } \\
\hline Yes & 15 & 75 \\
\hline No & 5 & 25 \\
\hline \multicolumn{3}{|l|}{ Province } \\
\hline City & 19 & 95 \\
\hline Country & 1 & 5 \\
\hline \multicolumn{3}{|l|}{ Smoking } \\
\hline Yes & 6 & 30 \\
\hline No & 14 & 70 \\
\hline \multicolumn{3}{|c|}{ Alcohol consumption } \\
\hline Yes & 2 & 10 \\
\hline No & 18 & 90 \\
\hline
\end{tabular}


During the treatment period the most common side effects were hair loss and fatigue. Not all the patients had complained about the same side effects. The distribution is summarized in Table 2.

Table 2. Side effect distribution

\begin{tabular}{|l|c|c|}
\hline Side Effects & $\begin{array}{c}\text { Yes } \\
\mathbf{n}(\mathbf{\%})\end{array}$ & $\begin{array}{c}\text { No } \\
\mathbf{n}(\mathbf{\%})\end{array}$ \\
\hline Emesis & $14(70)$ & $6(30)$ \\
\hline Hair loss & $15(75)$ & $5(25)$ \\
\hline Numbness (hand and feet) & $6(30)$ & $14(70)$ \\
\hline Anorexia, weight loss & $14(70)$ & $6(30)$ \\
\hline Fatigue & $16(80)$ & $4(20)$ \\
\hline Mucositis & $4(20)$ & $16(80)$ \\
\hline Diarrhea & $7(35)$ & $13(65)$ \\
\hline
\end{tabular}


Table 3. The family member/caregiver demographic variables

\begin{tabular}{|c|c|c|}
\hline Variable & \multirow{3}{*}{\multicolumn{2}{|c|}{$36.95(15-58)$}} \\
\hline Age & & \\
\hline \multirow[t]{2}{*}{ Mean (Ranger) } & & \\
\hline & $\mathrm{n}$ & $\%$ \\
\hline \multicolumn{3}{|l|}{ Gender } \\
\hline Male & 12 & 60 \\
\hline Female & 8 & 40 \\
\hline \multicolumn{3}{|l|}{ Education } \\
\hline None & 2 & 10 \\
\hline First Grade & 3 & 15 \\
\hline Middle Grade & 4 & 20 \\
\hline College & 7 & 35 \\
\hline Postgraduate & 4 & 20 \\
\hline \multicolumn{3}{|l|}{ Marital Status } \\
\hline Married & 15 & 75 \\
\hline Single & 5 & 25 \\
\hline \multicolumn{3}{|l|}{ Job } \\
\hline Yes & 7 & 35 \\
\hline No & 13 & 65 \\
\hline \multicolumn{3}{|l|}{ Family Member } \\
\hline Wife/husband & 9 & 45 \\
\hline Parent & 1 & 5 \\
\hline Sister/brother & 4 & 20 \\
\hline Child & 6 & 30 \\
\hline
\end{tabular}


All the caregivers were aware of the patient's diagnosis. Twenty-five percent of the patient had another family member with cancer history. Only $5 \%$ of the family member needed extra help during caregiving. The answer for the question about duration of the support and care during the treatment period was summarized in Table 4.

Table 4. Family support and care during treatment.

\begin{tabular}{|l|c|c|}
\hline \multicolumn{3}{|c|}{ Frequency of care/support of the patient by the family. } \\
\hline & n & $\%$ \\
\hline Continuously & 8 & 40 \\
\hline Often & 7 & 35 \\
\hline Only for the meals & 2 & 10 \\
\hline Rare & 3 & 15 \\
\hline
\end{tabular}

According to these data, gender, education, marital status, working, smoking and alcohol consumption are not statistically involved parameters. The results of SF36 test are shown in Table 5.

Table 5. SF - 36 test results.

\begin{tabular}{|l|c|c|c|c|c|c|c|c|}
\hline & \multicolumn{1}{c}{ Patient } & \multicolumn{7}{c|}{ Caregiver } \\
\cline { 2 - 11 } Parameter & \multicolumn{1}{c}{ Decreased } & \multicolumn{1}{c|}{ Normal } & \multicolumn{1}{c|}{ Decreased } & \multicolumn{2}{c|}{ Normal } \\
\hline & 7 & 35 & 13 & 65 & 5 & 25 & 15 & 75 \\
\hline Physical functions & 13 & 65 & 7 & 35 & 7 & 35 & 13 & 65 \\
\hline Physical role difficulty & 11 & 55 & 9 & 45 & 9 & 45 & 11 & 55 \\
\hline Pain relief & 14 & 70 & 6 & 30 & 8 & 40 & 12 & 60 \\
\hline General health perception & 9 & 45 & 11 & 55 & 10 & 50 & 10 & 50 \\
\hline Energy-vitality & 18 & 90 & 2 & 10 & 16 & 80 & 4 & 20 \\
\hline Social functionality & 13 & 65 & 7 & 35 & 13 & 65 & 7 & 35 \\
\hline Emotional role difficulty & 10 & 50 & 10 & 50 & 8 & 40 & 12 & 60 \\
\hline Mental health & & & & & & & $\%$ \\
\hline
\end{tabular}


Physical role difficulty parameter was decreased statistically significantly in patients with numbness $(\mathrm{p}=0.032)$. Similarly in this same group of patient's pain relief was also significantly decreased $(\mathrm{p}=0.008)$. Energy and vitality of the patients were significantly decreased in the numbness positive group $(p=0.024)$ however patients with mucositis were shown to have higher vitality $(\mathrm{p}=0.043$ ). Physical function parameters were lower in the diarrhea group $(\mathrm{p}=0.012)$ as well as pain relief parameter $(\mathrm{p}=0.043)$ and general health perception $(\mathrm{p}=0.032)$.

The SF-36 parameter analysis was not significant on behalf of the gender, education, and marital status of the family member but the single family members had lower physical function parameter results compared to the married ones $(p=0.037)$, also the general health perception results were lower in the single group $(\mathrm{p}=0.035)$.

\section{Discussion}

The treatment tolerance rates of our young Hodgkin lymphoma patients were quite good. Frequency of side effects and resistance to side effects were also highly positive. In our analysis, it was observed that the relatives of the patients interpreted only to the side effects that would change the quality of life. No psychological or social problems were encountered, which would necessitate quitting the treatment process for any patient or relatives (1).

Although there is evidence for the positive impact of social support on the overall well-being of a cancer patient, less is known about what types of social support are most important to patients diagnosed with lymphoma. Previous research has revealed that social support may be helpful when it is optimal and in the correct timing (1-4). The level of support offered differs between the siblings, the person supporting the patient should be the right person for the survivor in their social network. Some of the patients may expect higher levels of support from their caregivers, some of them may prefer instrumental support rather than spiritual support (5).

The partner or caregiver of the patient may experience equal or greater psychological distress during the treatment. This occurs especially when the patient is male, married and with children. Although there are a lot of interpretations of social support, the most frequently used four types are emotional, informational, appraisal and instrumental support (5). In any type optimal and sufficient support is a significant factor for improved quality of life. Some changes in the patient's social network may bring some relations closer or drive them apart. Across all contexts emotional support was most frequently mentioned by participants (9). 
Is There an Impact of Family Support on Treatment in Young Hodgkin's lymphoma Patients?

\section{Conclusion}

In conclusion, understanding the importance of family support and the need of the patient leads us to the optimal patient-based care and harmony for treatment.

\section{References}

1. Noone AM, Howlader N, Krapcho M, et al. SEER cancer statistics review. Bethesda,MD: National Cancer Institute;2017.

2. Shanbhag S, Ambinder RF. Hodgkin lymphoma: a review and update on recent progress. CA Cancer J clin. 2018;68:116-132

3. Flerlage JE, Metzger ML, Bhakta N. The management of Hodgkin lymphoma in adolescents and young adults: burden of disease or burden of choice? Blood. 2018; 132:376-384.

4. Holzner B, Fischofer M, Kemmler G, et al. Is higher income and educational status associated with poorer outcome in patients with Hodgkins disease? Eur J Haematol.2004;73:318-324.

5. Kelly E, Meara A, Hyer M, et al. Understanding the type of support offered within the caregiver, family and spiritual/religious contexts of cancer patients $\mathrm{J}$ Pain Symptom Manage. 2019;58: 56-64.

6. Kayser K, Watson LE, Andrade JT. Cancer as a "We-Disease": examining the process of coping from a relational perspective. Fam Syst Health 2007;25:404418.

7. Li Q, Loke AY. A systematic review of spousal couple-based intervention studies for couples coping with cancer:direction for the development of interventions. Psychooncology 2014:23:731-739.

8. Van Schoors M, De Mol J, Laeremans N, et al. Siblings experiences of everyday life in a family where one child is diagnosed with blood cancer: a qualitative study. J Ped Onco Nursing 2019;36(2):131-142.

9. Roper K, Cooley M, Powell M, et al. Health-related quality of life after treatment of Hodgkins lymphoma in young adults. Oncol Nurs Forum. 2013;40:349-360. 